\title{
Fun Pattern Based Learning Approach for Social Studies Learning during the Covid-19 Pandemic
}

\author{
Tetep ${ }^{1}$, Alni Dahlena 2 \\ DOI: 10.35445/alishlah.v13i3.1025
}

\begin{tabular}{|c|c|}
\hline Article Info & Abstract \\
\hline $\begin{array}{l}\text { Keywords: } \\
\text { Optimization; } \\
\text { Social Studies Learning; } \\
\text { Game-Based Learning; } \\
\text { Fun }\end{array}$ & $\begin{array}{l}\text { In the current situation, students consider a less exciting subject and less } \\
\text { motivated to learn social studies. So that students tend to be less enthusiastic } \\
\text { when participating in learning, especially in distance learning. This study aims } \\
\text { to describe social studies learning innovations for students based on fun } \\
\text { educational games for students. This research method is a qualitative method } \\
\text { using case study techniques directly on students and literature students. The } \\
\text { results of this study are; (1) social studies learning strategies based on fun } \\
\text { educational games related to simple social studies materials, but packaged in } \\
\text { interesting patterns for students so that they can increase students motivation } \\
\text { and interest in learning, especially in social studies learning; (2) Increasing the } \\
\text { optimization of students in understanding social studies materials with the } \\
\text { concept of strengthening reflection in social studies learning, especially in the } \\
\text { introduction of regions and cultures in Indonesia. }\end{array}$ \\
\hline
\end{tabular}

\begin{abstract}
Abstrak
Pada situasi saat ini, pembelajaran IPS yang dianggap oleh peserta didik sebagai mata pelajaran yang kurang begitu diminati. Sehingga peserta didik cenderung kurang begitu bersemangat ketika mengikuti pembelajaran terutama dalam pola pembelajaran jarak jauh. Tujuan dari penelitian ini adalah mendeskripsikan inovasi pembelajaran IPS pada peseta didik dengan berbasis game edukasi yang menyenangkan bagi peserta didik. Metode penelitian ini adalah metode kualitatif dengan menggunakan teknik studi kasus secara langsung pada peserta didik dan studi pustaka. Hasil dari penelitian ini adalah (1) Strategi pembelajaran IPS dengan berbasis game edukasi yang menyenangkan terkait materi-materi IPS yang sederhana, namun dikemas dengan pola yang menarik bagi peserta didik, sehingga dapat meningkatkan motivasi dan minat belajar peserta didik khususnya dalam pembelajaran IPS; (2) Meningkatkan optimalisasi Peserta didik dalam memahami materi-materi IPS dengan konsep refleksi penguatan dalam pembelajaran IPS terutama dalam pengenalan wilayah dan kebudayaan yang ada di Indonesia.
\end{abstract}

Kata kunci:

Pengoptimalisasian;

Pembelajaran IPS;

Game Based Learning; Fun

\footnotetext{
${ }^{1}$ Pendidikan Ilmu Pengetahuan Sosial, Institut Pendidikan Indonesia, Garut-Jawa Barat Email: tetep@institutpendidikan.ac.id 2 Pendidikan Ilmu Pengetahuan Sosial, Institut Pendidikan Indonesia, Garut-Jawa Barat Email: alni.dahlena@gmail.com
} 


\section{INTRODUCTION}

Everyone has the same opportunity to acquire knowledge through moral and social education, where a person has the right to an education. However, it is undeniable that there are problems and challenges in the distance learning process. Of course, the challenge is learning from the situation and conditions before the Covid-19 pandemic. Where the problems and challenges include the difficulties of students in learning, among others, less effective learning time so that the teaching and learning process does not run properly, which causes students to find it difficult to understand the lesson, then the limitations of students in understanding technology used as learning media. During the Covid-19 pandemic, the tendency of students to play more than participating in distance learning and the lack of interest and motivation of students to learn amid current conditions.

In general, the dominant factor in building human resources is following the times, which requires students to understand and follow the development of information technology as a supporting medium in distance learning activities (In'am, 2015). Meanwhile, according to Suprapti (2015), education is an investment in preparing quality human resources and preserving the value system that develops in life through the transfer of knowledge. So that in the situation of the Covid19 pandemic, the role of learning media in the learning and teaching process is significant for educators to carry out at this time because the role of learning media can be used to channel the sender's message to the recipient and through learning media can also help students to explain something. They were delivered by the educator. With these tools, teachers and students can communicate more steadily and lively, and the interactions are multi-directional. Media contains messages as learning stimulants and can foster learning motivation not to become bored in achieving learning goals. The use of digital media in learning today is indeed a demand, thus demanding the ability of teachers to have insight into today's digital media literacy. Hobbs (1999) explains that media literacy is the ability to access, analyze, evaluate and communicate messages in various forms. Media literacy-based research is indeed familiar and has been widely carried out both at home and abroad (Potter, 2004; Arke, 2004; Livingstone, 2004; Devito, 2008; Tormero, 2009; European Commission, 2009; Chen, 2011; Lin, 2013; Miocic, 2014, Tetep \& Suparman, A. 2019, Adiputra, 2008; Syukri, 2012; Arifianto, 2012; Adiarsi, 2015; Muttaqin, 2016; Yuniarin, 2017; Sholihudin, 2017). Digital media contains a person's ability to convey information that is beneficial and beneficial to the public, so digital media literacy does not only talk about the lives of individuals but how they as individuals live to uphold humanity (Fromm (1955, in Funk 1998:221) as quoted by Tetep (2015).

The primary purpose of learning Social Sciences is to create people's lives within the social sphere and in a state order with good social capital. Based on the results of research from the World Bank (1999, in Smith, 2009), social capital refers to the norms, institutions, and social relationships that shape the quality of social interaction in society, allowing people to work together. The ability to cooperate is also related to how a person can build socialization and participation both with the media directly or indirectly, in writing and orally (Tetep, 2014, 2019). Social studies education is directed at how students can live in society and solve problems in their lives by being equipped with knowledge, attitudes, and skills in social studies education materials, as a simplification of the social sciences used for educational purposes (Wesley, 1937; NCSS, 1993; Somantri, 2001). Social studies education is rich in human values, so it is more about value-based education on how to prepare to be a good citizen, by the social studies education tradition, namely 1) Social Studies as Transmission, 2) Social Studies as Social Sciences, 3) Social Studies as Reflective Inquiry.

According to Mulyana (2014), Social Sciences is science that studies humans in all aspects of their lives, their characteristics, their behavior, both individually and collectively, in small and large scopes, and interactions in their environment. Social Science Education is a subject that studies a lot about actions, behavior, and everyday human habits (Tetep et al., 2020) that cannot be separated from the context of interactions between individuals and other individuals. At the same time, Social 
Science is one of the contents of integrative thematic learning, which is linked to other subjects and integrated into learning themes. Fadlillah (2014) stated that what is meant by an integrated thematic approach is that learning is made per theme by referring to the characteristics of students and carried out by students in an integrated manner between one theme and another as well as between one subject and another.

Based on the opinion of Somantri (2001: 92), social science education is a simplification or adaptation of the social sciences and humanities disciplines, as well as basic human activities that are organized and presented scientifically and pedagogically/psychologically for educational purposes. Of course, learning social sciences is the basic foundation that becomes an important element in people's lives. Through social science, learning can be the basis for realizing the community's social life.

The development of online learning is in line with the phenomenon of the Covid-19 pandemic, which has been a challenge in the education sector. So that in the learning process in the scope of the educator unit switch to utilizing information technology online. Based on a statement from Dewi (2020), the concept of face-to-face learning is switching to distance or online learning as learning which in the process utilizes the internet network. Online education is still being implemented to continue educational activities during this COVID-19 pandemic and provide meaningful learning experiences for students.

Conception in the learning process during the Covid-19 pandemic, which emphasizes technological progress, is very influential as a learning medium in the current situation. Based on the opinion of Astuti \& Febrian (2019) which states that with technological advances, the problem of distance and time in learning can be overcome with distance learning (online), especially in social studies learning, where students in the learning process need to be given reinforcement as a reflection in understanding learning materials.

Based on the opinion of Tafonao (2018), states that the role of the media is the role of learning media in the learning and teaching process is very important to be carried out by educators today because the role of learning media can be used to channel the sender's message to the recipient and through learning media can also help participants students to explain something conveyed by the teacher. With these tools, teachers and students can communicate more steadily and lively, and their interactions are multi-directional. Media contains messages as a learning stimulant and can foster learning motivation not to become bored in achieving learning goals.

The concept of a fun learning model through educational games is an effort to maximize continuous learning activities through interaction between students and presenting subject matter in games (Darmawan, 2012). In this regard, in the learning process. Then according to Warsita (2008) said that the principles of behaviorism such as the activeness of students in the learning process, logical sequence of material, learning programs using the concept of stimulation, response, reinforcement factors (reinforcement), and feedback (feedback) until now there are still many applied in developing programs and computer-based learning media. According to this learning theory, learning is a process of behavior change that occurs due to a response to a particular situation or stimulus. A person is said to have learned if he shows a change in his behavior.

The need for creative learning methods to encourage students' motivation and enthusiasm for learning, then the application of game-based learning is a game made to stimulate thinking power, including increasing concentration and solving problems, especially in the current COVID-19 pandemic conditions. An effective interactive learning technique for early childhood students is to use educational games. This is because most students at an early age have a high curiosity about all those in the surrounding environment (R. A. Rahman \& Tresnawati, 2016). Through a learning- 
based game application model, of course, it can provide education through learning innovations that can increase students' learning motivation, especially in social studies learning, where game-based education will prioritize to support the learning process with the concept of playing while learning. For some students, the word learning will feel very scary, so it is hoped that with this interesting educational game, students will not realize that what they are doing includes learning, and students will be happy and willing to learn (Pesertadiknto \& Putra, 2013 ).

Thus the contextual problems that occur in distance learning conditions, especially in Social Sciences. Of course, it is a challenge for students to take part in learning. Technological limitations become an important element in supporting learning activities, the level of interest, and students' learning motivation in Social Sciences subjects which are still less attractive to students and considered boring.

\section{METHODS}

The research method used in this research is qualitative research by looking for data in case studies on students and direct observation on students. According to Sugiyono (2010), qualitative research has a function to determine the focus of research, select informants as data sources, collect data, assess data quality, interpret data and draw conclusions from the findings. This research was conducted by collecting descriptive data by conducting case studies on students, with a population of all students at the SMP/MTs level in the surrounding environment, and taking a sample of 10 students in Kampung Teureup, Tangerang, Banten representing. Sources of data used in this study include primary data and secondary data. Data collection techniques were carried out using interview techniques, documentation techniques, and case studies. The instruments in this study were a list of questions, interview guidelines, a camera to record images, and other tools. Qualitative data analysis was carried out by a case study approach so that data analysis was carried out by examining the answers collected from the research subjects. In this research, the researcher acts as a research instrument.

\section{FINDINGS AND DISCUSSION}

\section{Strategy for Realizing Fun Pattern Based Learning in the Covid-19 Pandemic}

Implementation of the concept of based learning fun in social studies learning is as a pattern that is used as a guide in reflecting on distance learning or online learning and to determine learning tools, including books, films, curriculum, and others (Joyce and Weil in Rusman, 2013: 133). Of course, each learning pattern directs the teacher to design learning to help students achieve the learning objectives. In practical and meaningful learning, students are actively involved because students are the center of learning activities and the formation of competence and character. Through learning activities, implementing and innovating fun-based learning models can provide a strategy to re-awaken students to continue learning in current conditions. Of course, this can improve the ability and understanding of students regarding learning materials.

The concept of game-based learning fun in social studies learning can be used in the distance learning process, which is carried out for elementary and junior high school students. All participants took part in the program of activities realized by students with the progress of actively asking questions during the activity and responsive to the realization of game-based learning fun in the learning process. This activity is carried out by students directly by showing a map image, the traditional culture of each region, and the names of the heroes of the Indonesian independence struggle.

Based on the application of a fun game-based social studies learning pattern with a strategy of showing pictures to students and video footage to students related to social studies materials such as the introduction of regions in Indonesia, culture, and the solar system. So that students must be able to answer quizzes on the pictures of the areas that have been shown and on the videos that have 
been shown. Thus, students can participate in these learning activities by getting excited and increasing their motivation to keep learning, especially in social studies learning. So that students' learning patterns can be helped and can understand the learning materials that have been studied and can be understood in more depth. This learning pattern can form students understand the primary social studies material.

\section{Optimization of Social Studies Learning Reinforcement with Fun Pattern Based Learning}

Realization of optimization in providing reinforcement and reflection to students in learning, especially Social Science Subjects from the material or tasks owned by students, which is collaborated with the concept of game-based learning fun through providing simple social studies learning reflections starting from area introduction, culture, and a brief history of Indonesian independence. The game is in the form of a quiz given to students-using science and technology that is understood and helps students understand the material. However, not only in social studies learning material. So from the results of research and service, namely:

a. Improving the competence of students in understanding social studies learning through fun pattern-based learning

Reflection on strengthening social studies learning with a game-based learning fun pattern as a strategy for implementing effective learning methods. Through training, the application of fun game-based learning can increase students' competence to deliver learning materials with fun innovations and models and collaborate with technological developments. So that students, in particular, have competence in understanding and implementing social studies learning, which can increase students' interest and motivation in learning and in understanding and mastering technology.

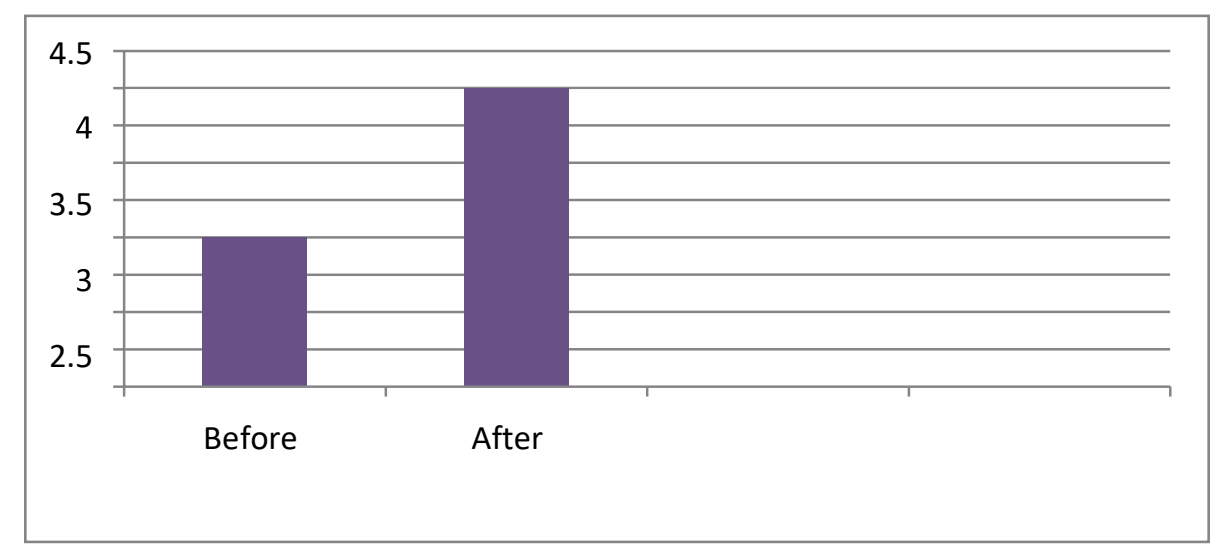

\section{Graph 1. Percentage of before and after implementing game based learning fun}

Based on the graph above, the role of game-based learning fun education, which is reflected in each student, has a significant change. The strength of the educational game-based learning model can have a good influence on the condition of students. Through the aspect of cooperation and adherence to the established learning models and media, the realization in the surrounding environment that based on the graph above, participants students in responding to government policies related to the conditions of the spread of the Covid-19 pandemic, where students follow learning with a gem pattern that significantly increases their learning motivation. However, it cannot be denied that student learning activities are different because of students' different activities or needs. Thus, students continue to reflect their interests and motivation as a form of student interest in the learning process that is packaged in a fun way. 
The results of this study are supported by various previous studies, including Taquero et al. (2021), which stated that it turned out that Bandicam made online learning more effective. Kalleny (2020) also revealed in his research that graph theory material is more effective when taught using the Bandicam application. According to Sutton \& Jorge (2020), video technology provides convenience in learning. Video technology provides opportunities for teachers and students to learn through audio and visual simultaneously.

This media can be used to deliver learning material realistically and concretely, which is impossible to convey through print media. One of the efforts to improve learning outcomes during the pandemic is the development of online application-based learning media, for example, by presenting video media in the presentation of learning materials. Video media such as Bandicam and so on have better capabilities.

Besides Bandicam, it turns out that other applications such as Sparkol Videoscribe are also effective, such as expressed by Vanlue (2021); Nunes \& Cruz (2021) that learning media uses applications such as video scribe can be an alternative media that can increase interest in learning student. Online application media such as learning videos based on zenius.net also can increase motivation and understanding of learning for students (O'Fareel et al., 2021). In addition to graph theory material, student learning outcomes in Social Science Cognitive learning also increase Dimitra et al. (2020).

From offline to online, the latest learning requires all educators to create a variety of media and learning applications that make it easier for students to learn (Zainuddin \& Keumala (2021). The use of technology in Indonesia today is entering the study of the various possibilities for developing and applying technology in education. The whole school system should be moderate and familiar with the technology that enables students to learn faster, better, and wiser. Technology is the key to a better future school model. Therefore that all educators in Indonesia, in terms of conveying the educational process with required to use the latest technology (Ang et al., 2020)

\section{b. Increasing students' interest in the social studies learning process}

Basically, through reflection on strengthening social studies learning by realizing learning with a fun educational game model (game-based learning fun), of course, it can provide increased student learning outcomes. It can provide a good response in increasing students' knowledge of Indonesia's region, culture, and history of independence. So that through the educational game learning model, it can provide fun learning patterns so that it can generate interest and enthusiasm for learning in students, especially amid the Covid-19 pandemic.

To create and fun learning, various skills are needed, including teaching skills. Teaching skills are quite complex professional competencies, as an integration of various teacher competencies as a whole and comprehensively, likewise, in creating fun social science education learning. One of the means that teachers can use is to utilize Computer Information Technology (ICT) as a learning medium. The use of learning media can lead to the use of time effectively and efficiently. Learning media can also be a unique attraction to motivate students in learning. From an economic point of view, IT-based learning media are more affordable to be empowered.

In recent years, many studies have revealed that game-based learning is very effective if applied in learning. Game-based learning has a vital role in influencing students' motivation and can make students feel happy, more enthusiastic, challenged, and establish cooperation between friends (Killi et al., 2021). Other research also mentions that game-based learning, especially card games, can increase attention, motivation, and curiosity (Umbara et al., 2021).

To find out the extent to which students have carried out their learning process well, it is necessary to measure the learning abilities of these students. The results of these measurements are what is called learning achievement. Learning achievement is defined as the level of humanity possessed by students in accepting, rejecting, and assessing the information obtained in learning 
(Dewantara et al., 2020). In line with this definition, other researchers also argue that learning achievement is an achievement obtained by students in learning activities (doing assignments, tests, or exams) in the form of values or numbers obtained from evaluations (Umbara et al., 2021). Learning shows the extent to which concepts or competencies that become learning objectives (instructional objectives) or behavioral objectives (behavioral objectives) can be mastered by students at the end of the teaching period (Rochmah, 2021).

\section{c. Implementing the concept of game-based learning fun in social studies learning during the Covid-19 pandemic}

Implementing game-based learning fun in social studies subjects applied to students has a good influence on students. This can be seen through the response of students who are very good when realizing the learning process. So that students can actively participate in learning and participate in learning activities.

Learning with the game-based learning model can change the learning paradigm initially a teacher center to a student center. Based on constructivist learning theory, it is stated that learning will be more meaningful when students are involved in constructing their knowledge. This theory emphasizes providing opportunities for students to make judgments and interpretations of situations that they experience themselves (Hussain, 2012). One of the innovative learning models that involve students in problem-solving activities and provide opportunities to work autonomously to construct their way of learning is game-based learning. This learning model helps students build meaningful learning and stimulates their development by providing a fun learning experience. This fun learning experience, of course, will impact the interests and motivation of students. Students' increased interest and motivation students increased interest and motivation will trigger curiosity and lead to a further and deeper exploration of what they have done (Duggal et al., 2021). Similar research also found the same thing, that game-based learning can improve student achievement and learning attitudes (Syaharuddin et al., 2021). Therefore, the integration of games in the learning process showed favorable results where students showed positive changes in motivation and learning achievement. Students will learn how to work together, take turns, share material, and correct each other's mistakes during the play process. Lecturers should play an important role as facilitators and always guide at the right time and situation because games in the learning process do not mean students are allowed to play without direction and supervision. Play is quite important in education because they will learn a lot through playing activities. Therefore, it is hoped that the results of this study can serve as a guide for teachers in integrating play activities as part of the learning process.

In practice, there are several problems experienced by teachers in learning social sciences, including (a) the high level of abstraction of the material, resulting in low student learning motivation and is often an unsatisfactory reason in achieving student learning achievement; (b) lack of learning resources related to interpersonal skills; and (c) curriculum demands require teachers to be more creative in developing learning models. However, in learning, the classroom atmosphere tends to be boring because most teachers only present what is in the book conventionally and only focus on the completeness of the curriculum without paying attention to the expected learning outcomes.

\section{CONCLUSION}

Based on the research results, the strategy is carried out to minimize the problems that occur, namely by reflecting on strengthening student learning in social studies subjects, which is carried out with fun learning patterns and educational games. Of course, these learning models and innovations can increase students' participation, interest, and motivation to learn amid the Covid19 pandemic condition. So that through a fun learning pattern, it can certainly provide new 
knowledge and enthusiasm and motivate students to participate in the learning process actively. Thus, strengthening social studies learning with a fun educational game pattern can significantly improve students' learning. So social studies learning can be carried out in a fun way and can improve students' social interaction with educators and friends and be able to cooperate.

\section{REFERENCES}

Abdullah, et al,. (2012). The Impact of Video Game in Childern's Learningof Mathematics. International of Journal Social, Mangement, Economics and Business Engineering Vol 6 No 4.

Adam, steffi dan M. T. . (2015). Pemanfaatan Media Pembelajaran Berbasis Teknologi Informasi Bagi Peserta didik Kelas X Sma Ananda Batam. CBIS Journal, 3 No 2(ISSN 23378794), 7890.

Adiputra, W. M. (2013). Literasi Media dan Interpretasi atas Bencana. Adiputra, wisnu martha. 2008. Literasi Media dan Interpretasi atas Bencana. [online], diakhttp://jurnalsospol.fisipol.ugm.ac.id/.

Adler, P., Kwon S. (2000). Social Capital: the good, the bad and the ugly. In E. Lesser (Ed). Knowledge and Social Capital: Foundations and Applications. Butterworth-Heinemmann.

Ang, J. W. J., Ng, Y. N. A., \& Liew, R. S. (2020). Physical and digital educational escape room for teaching chemical bonding. Journal of Chemical Education, 97(9), 2849-2856.

Arifianto, S. 2. (2013). Literasi Media dan Pembelajaran Peran Kearifan Lokal Masyarakat. Aptika. .

Arke, E. (2004). Media Literacy and Critical Thinking. information journal.

Avianto, Y. F., \& Tan A. S. P. (2018). Pembelajaran Aksara Jawa untuk Peserta didik Sekolah Dasar dengan Menggunakan Media Board Game. Jurnal Aksara. Universitas Kristen Satya Wacana. Vol. 30, No 1.

Brooks, S. L. (2013). Social Media Usage: Examination of Influencers and Effects. United States: Published by ProQuest LLC.

Buckingham, D. (2003). Media Education: Literacy, Learning and Contemporary Culture. Cambridge, UK: Polity Press/Blackwell.

Cohen, S., Prusak L. (2001). In Good Company: How Social Capital Makes Organization Work. London: Harvard Business Pres.

Coleman, J., (1990). Foundations of Social Theory. Cambridge Mass: Harvard University Press.

Commission, E. (2009). Study on assessment Criteria for Media Literacy levels. Brussels: European Commission.

Covington, W. G. (2004). Creativity in Teaching Media Literacy. International Journal of Instructional Media, 119-124.

Cox, Eva. (1995). A Truly Civil Society. Sydney:ABC Boook.

Cresswell, J. W. (2008). Research Design, Quantitative and Qualitative Approach. California: Sage Publication.

Dewantara, D., Wati, M., Misbah, M., Mahtari, S., \& Haryandi, S. (2020, March). The effectiveness of game based learning on the logic gate topics. In Journal of Physics: Conference Series (Vol. 1491, No. 1, p. 012045). IOP Publishing.

Dewi, P.S., \& Septa, H.W. (2019). Peningkatan Kemampuan Pemecahan Masalah dan Disposisi Matematis Peserta didik dengan Pembelajaran Berbasis Masalah. Mathema: Journal Pendidikan Matematika, 1 (1), 31-39.

Didiknto, Y., \& Putra, B. E. (2013). Rancang Bangun Aplikasi Mobile Game Edukasi Ilmu Pengetahuan Alam Untuk Peserta didik Kelas VI Sekolah Dasar. Rancang Bangun Aplikasi Mobile Game Edukasi Ilmu Pengetahuan Alam Untuk Peserta didik Kelas VI Sekolah Dasar, Vol. 5 No. 4.

Dimitra, K., Konstantinos, K., Christina, Z., \& Katerina, T. (2020). Types of Game-Based Learning in Education: A Brief State of the Art and the Implementation in Greece. European Educational Researcher, 3(2), 87-100.

Duggal, K., Singh, P., \& Gupta, L. R. (2021). Intrinsic and Extrinsic Motivation for Online Teaching in COVID-19: Applications, Issues, and Solution. Emerging Technologies for Battling Covid19: Applications and Innovations, 327-349.

Efendi, Agus. (2014). Implementasi Kearifan Budaya Lokal pada Masyarakat Adat Kampung Kuta sebagai Sumber Pembelajaran IPS. Jurnal Sosio Didaktita, Vol. 1, No. 2. 
Fadlillah, M. (2014). Implementasi Kurikulum 2013 dalam Pembelajaran SD/MI, SMP/MTs, dan SMA/MA. Yogyakarta: Ar-Ruzz Media.

Fukuyama, F (1995). Social Capital and The Global Economy. Foreign Affairs, 74(5), 89-103. In Elinor Ostrom and T.K. Ahn. 2003. Foundation of Social Capital. Massachusetts: Edward Elgar Publishing Limited.

Fukuyama, F (1995). Trust: The Social Virtues and The Creation of Prosperity. New York: Free Press. Fukuyama, F (2000). Social Capital and Civil Society. International Monetary Fund Working Paper, WP/Oo/74, 1-8. In Elinor Ostrom and T.K. Ahn. 2003. Foundation of Social Capital. Massachusetts: Edward Elgar Publishing Limited.

Haryanto, Y. (2017). Literasi Media Di Kalangan Remaja Kota Dalam Penggunaan Media Sosial. Unair press.

Hasbullah, J., (2006). Sosial Kapital: Menuju Keunggulan Budaya Manusia Indonesia. Jakarta: MRUnited Press.

Hobbs, R. (1998). The Seven Great Debates in the Media Literacy Movement. Journal of Communication , 16-32.

Iriantara, Y. (2009). Literasi Media, Apa, Mengapa, Bagaimana. Bandung: Simbiosa Rekatama Media.

Ismail S. (1999). Social Capital A Multifaceted Perspective. Washington DC: World Bank.

Kalleny, N. K. (2020). Advantages of Kahoot! Game-based formative assessments along with methods of its use and application during the COVID-19 pandemic in various live learning sessions. Journal of Microscopy and Ultrastructure, 8(4), 175.

Kiili, K. J. M., Lindstedt, A., Koskinen, A., Halme, H., Ninaus, M., \& McMullen, J. (2021). Flow Experience and Situational Interest in Game-Based Learning: Cousins or Identical Twins. International Journal of Serious Games, 8(3), 93-114.

Lin, T.-B. e. (2013). Understanding New Media Literacy: An Explorative Theoritical Freamework. Educational Technology \& Society. -: http://e-resources.perpusnas.go.id:2057/docview/1.

Livingstone, S. (2008). Young People Media. London: Sage.

Mihailidis, P. \&. ( 2013). Media Literacy as a Core Competency for Engaged Citizenship in Participatory Democracy. Sage Journals, 1611-1622.

Mulyana, Eldi. (2014). "Model Pembelajaran Generatif Sebagai Upaya Meningkat Pemahaman Konsep IPS Pada Peserta Didik”. Jurmal Pendidikan Ilmu Pengetahuan Sosial Vol. 23 No. 2 Desember 2014, pp. 26-33.

Nunes, E., \& Cruz, M. (2021, March). Game-Based Learning: A Push for Introducing a C (Classroom)-MORPG. In World Conference on Information Systems and Technologies (pp. 663-670). Springer, Cham.

O’Farrell, E., Yilmaz, M., Gulec, U., \& Clarke, P. (2021, September). PlaySAFe: Results from a Virtual Reality Study Using Digital Game-Based Learning for SAFe Agile Software Development. In European Conference on Software Process Improvement (pp. 695-707). Springer, Cham.

Potter, W. J. (2004). Theory of Media literacy : A Cognitive Approach. London : Sage Publications.

Putnam, RD (1993), "The Prosperous Community: Social Capital and Public Life, dalam The American Prospect, Vol.13, halaman 35-42.

Recepoğlu, E. (2005). The importance of media literacy education in the process of teacher Training in higher education. The International Journal of Social Sciences. .

Reimers, F., Schleicher, A., Saavedra, J., \& Tuominen, S. (2020). Supporting the continuation of teaching and learning during the COVID-19 pandemic. Oecd, 1(1), 1-38.

Rochmah, I. N. (2021). Development of Game-based Learning using A Mobile App for Students Fractions Learning. In Journal of Physics: Conference Series (Vol. 1737, No. 1, p. 012033). IOP Publishing.

Sintema, E. J. (2020). Effect of COVID-19 on the Performance of Grade 12 Students: Implication for STEM Education. EURASIA Journal of Mathematics, Science and Technology Education, Vol. 16 No. 7, pp. 1-6.

Solow, R. M. (1999). Notes Social Capital and Economic Performance. In Partha D., Ismail S., (1999). Social Capital A Multifaceted Perspective. Washington DC: The World Bank. Schaefer, D. J. 
(2005). Media literacy and Singapore: Lessons from the Asia context. Paper presented at a nondivisional workshop held at the meeting of the International Communication Association. International Communication, -.

Somantri, N. (2001). "Menggagas Pembaharuan Pendidikan IPS”. Bandung: PIPS-FPIPS UPI dan PT. Remadja Rosda Karya.

Sutton, M. J., \& Jorge, C. F. B. (2020). Potential for radical change in Higher Education learning spaces after the pandemic. Journal of Applied Learning and Teaching, 3(1).

Syaharuddin, S., Mutiani, M., Handy, M. R. N., Abbas, E. W., \& Jumriani, J. (2021). Building Students' Learning Experience in Online Learning During Pandemic. Al-Ishlah: Jurnal Pendidikan, 13(2), 979-987.

Syaharuddin, S., Mutiani, M., Handy, M. R. N., Abbas, E. W., \& Jumriani, J. (2021). Building Students' Learning Experience in Online Learning During Pandemic. Al-Ishlah: Jurnal Pendidikan, 13(2), 979-987.

Tafonao, T. (2018). Peranan Media Pembelajaran Dalam Meningkatkan Minat Belajar Mahasiswa. Jurnal Komunikasi Pendidikan, Vol. 2 No. 2, pp. 103.

Tetep (2017). Menggali Nilai-nilai Karakter Sosial dalam Meneguhkan Kembali Jati Diri ke-Bhinekaan Bangsa Indonesia. Prosiding Konferensi Nasional Kewarganegaraan III. 11 November 2017. P-ISSN 2598-5973, e-ISSN 2599-008X Prodi PPKn UAD Yogjakarta. http://eprints.uad.ac.id/9928/1/372-379\%20Tetep.pdf

Tetep, (2021), Social Capital and Digital Media Literacy Transformation from The Perspective of Social Science in The Era of Covid 19 Pandemic. Review of Internastional Geographic Edcuation.ISSN:2146-0353.@Rigeo (11)3. Summer 2021. Doi: 10.33403/rigeo.800561.

Tetep, Asep Suparman. 2019. Students' Digital Media Literacy: Effects on Social Character. International Journal of Recent Technology and Engineering (IJRTE) ISSN: 2277-3878, Volume-8 Issue-2S9, September 2019.

Tetep, dan A. Suparman. (2019). Students' Digital Media Literacy: Effects on Social Character. IJRTE Journal.

Tetep, e. (2019). Opportunities or Challenges? Building Student Social Character through WhatsApp-Based Project Citizen in Disruptive Era. Jurnal ICBLP, ---.

Tetep, etc. (2020). Penguatan Literacy IPS dalam Paradigma Kebijakan Social Distancing di Era Pandemi Covid 19 (Studi Pemahaman Dasar Siswa SMP di Wilayah Selatan Kabupaten Garut). IOP Publishing.

Tetep, etc. (2021). Strengthening Social Studies Literacy in the Social Distancing Policy Paradigm in the Covid-19 Pandemic Era (Study of Basic Understanding of Junior High School Students in the South Region of Garut Regency). Advances in Social Science, Education and Humanities Research, Volumen 525. Atlantis Press.

Tetep. (2014). Optimalisasi Peran Iklim Sekolah bagi pembentukan karakter sosial Peserta didik. International Seminar The Social Studies Contribution to Reach Periodic Environmental Education into Stunning Generation 2045 (pp. 140-155). Bandung: PIPS Pascasarjana UPI.

Toquero, C. M. D., Sonsona, D. A., \& Talidong, K. J. B. (2021). Game-based learning: Reinforcing a paradigm transition on pedagogy amid COVID-19 to complement emergency online education. International Journal of Didactical Studies, 2(2), 10458.

Umbara, U. Munir., Susilana, R., \& Puadi, EFW (2021). Algebra dominoes game: Re-designing mathematics learning during the covid-19 pandemic. International Journal of Instruction, 14(4), 483-502.

Vanlue, A. B., Bartels, P., \& Barrong, T. (2021). Joystick Education: Online Game-Based Learning.

Woolcock, M. (1998). Social Capital and Economic Development: Toward a Theoretical Synthesis and Policy Framework. Theory and Society, 27 (1),151-208. In Elinor Ostrom and T.K. Ahn. 2003. Foundation of Social Capital. Massachusetts: Edward Elgar Publishing Limited.

Zainuddin, Z., \& Keumala, C. M. (2021). Gamification Concept Without Digital Platforms: A Strategy For Parents On Motivating Children Study At Home During Covid-19 Pandemic. PEDAGOGIK: Jurnal Pendidikan, 8(1), 156-193. 